\title{
Parenting Style and Adversity on Learning Achievement of Muhammadiyah Elementary School Surabaya in the New Normal Era of Covid-19
}

\author{
Ratno Abidin ${ }^{1} \quad$ Mustaji $^{2} \quad$ Fajar Arianto $^{2} \quad$ Asy'ari $^{3}$ \\ 1.Universitas Muhammadiyah Surabaya (UMS), Faculty of Teacher Training and Education, Doctorate of \\ Education Technology Department at Universitas Negeri Surabaya (UNESA) Surabaya Indonesia \\ 2.Master Degree at Universitas Negeri Surabaya (UNESA) Surabaya, Doctorate of Education Technology \\ Department at Universitas Negeri Surabaya (UNESA) Surabaya Indonesia \\ 3.Universitas Muhammadiyah Surabaya (UMS), Faculty of Teacher Training and Education, Indonesia
}

\begin{abstract}
This study aimed to describe a correlation between parenting style and adversity towards 5th-grade students' learning achievement at Muhammadiyah Elementary School (SD Muhammadiyah 18 Surabaya). The method used was a correlation technique. This research was ex-post-facto, which reveals facts that have happened and the causes cannot be interference. Correlational techniques were used to show the degree of correlation between parenting styles and adversity variables on Grade 5 Students of SD Muhammadiyah 18 Surabaya learning achievement. Based upon the results carried out, it can be concluded that (1) there was a positive and significant influence between parenting styles on the achievement of 5th-grade students of SD Muhammadiyah 18 Surabaya, (2) there was a positive and significant influence between adversity on the achievement of grade 5 student at SD Muhammadiyah 18 Surabaya and (3) there is a positive and significant influence between parenting (X1) and adversity (X2) on the learning achievement of grade 5 students of SD Muhammadiyah 18 Surabaya shown through multiple regression tests $(\mathrm{R} 1,2)$ with a coefficient of 0.28 and the determinant coefficient of $r_{-}(2 x, y)$ or the contribution of the influence of parenting on learning achievement is $23 \%$. Thus, parenting style and adversity collectively do not affect student achievement in grade 5 SD Muhammadiyah 18 Surabaya as much as $8.1 \%$.
\end{abstract}

Keywords: parenting, adversity, learning achievement, student, Muhammadiyah Elementary School

DOI: $10.7176 / \mathrm{JEP} / 12-27-11$

Publication date: September $30^{\text {th }} 2021$

\section{INTRODUCTION}

Parents' role is important in being responsible for children's needs, especially in the context of fostering, honing, and loving (Luo et al., 2021)(Deng \& Tong, 2020). Fostering is a way for parents to educate their children to have appropriate behavior with their development level. Honing is an act of parents exploring their children's abilities according to their children's talents (Qin et al., 2020), (Stern et al., 2019). Meanwhile, compassion is how parents give their children their affection (Si et al., 2020), (Qin et al., 2020). Parenting patterns in interacting with children, such as communicating, educating, and caring for parents, need to be done in an ongoing manner (Lavrič \& Naterer, 2020). With parenting that parents apply, children can interact with their environment about the world around them and know the life relationships that apply in their environment (Covin et al., 2020).

The parenting style carried out to their children, whether done in the city's area, generally has different types. One of which is usually called permissive parenting, defined as the pattern of parents' behavior in interacting with their children, free to do what they want - done without question (Xia, 2020), (van Herwijnen et al., 2020). Authoritarian parenting, namely parenting in which parents apply rules and boundaries that absolutely must be obeyed, without allowing them to argue that they will be threatened and punished if the child does not comply. This kind of parenting has an impact on the child's self-distrust (Qin et al., 2020). What parents need to do is that parents can understand them as the primary and first educators for their children at home (Gralewski \& Jankowska, 2020).

On the other hand, there is also a family in building, namely in a democratic parenting style, namely in instilling discipline in children (Yaffe, 2020), (G. Chen et al., 2020). Parents who apply a parenting style that shows and respects the child's freedom, with understanding guidance between the child and the parents, and provides a rationale and objective explanation, will better impact the child's personality (Benoy \& Morley, 2020). There is also neglect parenting, which is a parenting style where parents are not involved in their children's lives (Yang et al., 2020),(DeZelar \& Lightfoot, 2020). Parents who apply parenting styles by neglecting their children as people and do not have much time with them, which in turn can cause the child's social skills to be reduced (Brosnan et al., 2020),(Mönkediek et al., 2020). Based upon the four types of parenting above, its implementation dramatically impacts the development of children's character directly, both positively and 
negatively, in daily life (Valashjardi et al., 2020), (Maftei et al., 2020).

Then from the parenting style, the impact also forms adversity in a child (Sharma, 2019). Adversity itself is individual intelligence in dealing with any difficulties that arise. If the child faced various life difficulties, the intelligence used is adversity (Lavrič \& Naterer, 2020),(Deng \& Tong, 2020). From this explanation, adversity is a child's ability to face any problem that he considers difficult but will still survive and try to solve it as well as possible to become an individual who has good quality (Paul \& Singh, 2020). Therefore a child can be formed if it accompanied by having confidence in doing tasks easily, responsible, and focused on completing the assigned task and having a creative spirit in completing the task so that it is not monotonous and boring for a child's life (Cheng et al., 2021).

In the context of intelligence that children have, there must be factors that support it, namely motivation, encouragement from within, and an unyielding attitude; these factors are referred to as adversity(O'Connor et al., 2020). According to (O'Dea et al., 2020), adversity is a person's intelligence in overcoming difficulties and surviving. The definition of adversity used in this study is the definition put forward.The adversity of other contexts, according to Pierce, states that it is the intelligence that a person has in overcoming difficulties and being able to survive. Based upon the definitions of several experts above, so adversity is a person's ability to use intelligence in dealing with and managing problems regularly and continuously so that they can solve these problems (Kroska et al., 2020),(Hendrix et al., 2020).

So, in other words, that as teachers must go through with challenges; and there is a need to improve their ability to withstand difficulties (Dragan, 2020). So, there is a need to understand children's adversity in their lives (Mönkediek et al., 2020). The ability to withstand adversity is an essential aspect of a child's quality of life. Then kids with high adversity outperformed those with low adversity (Yuqiong He et al., 2021). Adversity becomes very important, which must be instilled from an early age by parents as one of the first educators for their children without having to delay anymore (Putwain et al., 2020), (Xia, 2020). Children's success in facing all challenges through life cannot separate from people's role in shaping their personalities, who do not give up easily and never give up. On the other hand, in the context of adversity, according to (Paul \& Singh, 2020) that adversity as a prediction of successes is very useful to determine the way according to the difficulties faced by a person and leads to learning achievement achieved by students (O'Connor et al., 2020).

Therefore, children's success must be considered in the learning process from its difficulties, namely, the accuracy of understanding each child in their intelligence and their relationships with others (Fluss \& Lidzba, 2020), (Morard et al., 2018). Then, the educational process's success is based upon student achievement level (Ernst et al., 2020). According to (Sierra, 2020) and (Furusawa \& Brewster, 2019), learning achievement is achieving the perfection achieved by someone in thinking, feeling, and doing. Good learning achievement is affected by three cognitive, affective, and psychomotor aspects (Woo et al., 2019). On the contrary, children cannot have good achievement if they cannot meet the targets in the three criteria (Lycko \& Galanakis, 2019), (B orsting et al., 2020) because learning achievement is significant to be maximized in every child (J. Guo, 2018)(Hayes, 2020).

Meanwhile, learning achievement has varying definitions for each theory (Hammami et al., 2019). According to (Logan et al., 2020), learning achievement is students' success in meeting short or long-term goals in education. Student academic performance is strong student performance in a specific academic area. Meanwhile, another understanding that learning achievement is acquiring knowledge or skills developed by the subject matter is usually indicated by test scores or numeric values assigned by the teacher (Kyriakides et al., 2019), (Roh et al., 2020). Learning achievement itself is the result of learning achieved after going through the process of teaching and learning activities (P. Guo et al., 2020), (Sumiyoshi et al., 2020). Teachers valued students' learning achievement from the number of subjects they have studied (Horning et al., 2020), (Gerritsenvan Leeuwenkamp et al., 2019). According to (Kumpas-Lenk et al., 2018), each learning activity always expects to produce maximum learning.

On the other hand, in a deep understanding, learning achievement is a measured index that describes students' cognitive, affective, and psychomotor domains in an educational environment. (I. C. Chen et al., 2020), (Knoop-van Campen et al., 2020). Ongoing examinations or assessments usually measure study achievement, but there is no general agreement about how best to test or which aspects are most important (Paul \& Singh, 2020)(Bai et al., 2020). Student academic performance measured by the teacher using teacher-made tests or standardized tests (Dvorsky et al., 2021). Learning achievement is a measure of student success, so it is necessary to study aspects that can support learning achievement improvement and Indonesia's quality of education (Gatti et al., 2019), (Huizenga et al., 2019). In the process of achieving it, learning achievement is greatly influenced by various factors. One of the main factors that significantly influence learning success is a teacher's presence (Naik et al., 2020). Given that teachers' existence in the process of teaching and learning activities is very influential, then the quality of teachers should be considered (Oh et al., 2019), (Dvorsky et al., 2021).

Then, in the context of learning achievement, the school has made an effort to make achievement that has 
led Muhammadiyah 18 Surabaya Elementary School to gain the community's trust in fostering their sons and daughters. However, efforts must continue to improve quality-oriented to prepare students for global competition towards mastery of science and technology and other life skills (Brosnan et al., 2020). In this global competition era, the challenges ahead are getting more challenging, especially for parents in determining the right school choice for their children to achieve maximum learning achievement (Oh et al., 2019).

\section{METHOD}

The method or approach used in this research is the correlation technique. This research is ex-post-facto, revealing facts that have happened and the causes that cannot be interfered with. Correlational techniques are used to show the degree of correlation between parenting styles and adversity variables on Grade 5 Students of SD Muhammadiyah 18 Surabaya's learning achievement. The research was at SD Muhammadiyah 18 Surabaya. This research was in the first semester of the 2020/2021 school year with a sample of 100 students. There are two types of variables involved in this study: the independent variables denoted by X1 and X2, namely the variables of parenting and adversity, and the dependent variable, denoted by $\mathrm{Y}$, namely learning achievement. The data collection method used in this research is documentation and questionnaire methods. Data for the variables of parenting styles and adversity were obtained through questionnaires for parenting styles and adversity quotient using the Likert scale. The data on student achievement was obtained through the first semester assessment results for the academic year 2020/2021.

\section{RESULT AND DISCUSSION}

\section{Result}

Based upon the study results, data that includes parenting styles, adversity, and students' learning achievement at Muhammadiyah 18 Elementary School Surabaya, on average, 97\% of SD Muhammadiyah 18 students have high parenting styles and 3\% very high parenting styles. It was in Table 1 below.

Table. 1 Level of Parenting at $5^{\text {th }}$ Grade Students of SD Muhammadiyah 18 Surabaya

\begin{tabular}{llll}
\hline No & Classification & Number of Students & Percentage \\
\hline $\mathbf{1}$ & Very High & 3 & 3 \\
$\mathbf{2}$ & High & 97 & 97 \\
$\mathbf{3}$ & Moderate & 0 & 0 \\
$\mathbf{4}$ & Low & 0 & 0 \\
\hline Total & & 100 & 100 \\
\hline
\end{tabular}

While the adversity data was based on the results of research from 100 grade 5 students of SD Muhammadiyah 18 Surabaya, in general, it can be told that $62 \%$ have very high adversity and $38 \%$ have high adversity; the data was presented in table 2 .

Table 2 Adversity Level of $5^{\text {th }}$ Grade Student at SD Muhammadiyah 18 Surabaya

\begin{tabular}{llll}
\hline No & Classification & Number of Students & Percentage \\
\hline $\mathbf{1}$ & Very High & 62 & 62 \\
$\mathbf{2}$ & High & 38 & 38 \\
$\mathbf{3}$ & Moderate & 0 & 0 \\
$\mathbf{4}$ & Low & 0 & 0 \\
\hline Total & & 100 & 100 \\
\hline
\end{tabular}

Based upon the assessment of the mid-semester of first semester 2020/2020 grade 5 students of SD Muhammadiyah 18 , in general, it can be told that $75 \%$ have very high learning achievement with the highest score of 100 and the lowest 80. Data on student achievement of grade 5 SD Muhammadiyah can be seen in the table.

Table 3. Achievement Levels of $5^{\text {th }}$ Grade Student at SD Muhammadiyah 18 Surabaya

\begin{tabular}{llll}
\hline No & Classification & Number of Students & Percentage \\
\hline $\mathbf{1}$ & Very High & 75 & 75 \\
$\mathbf{2}$ & High & 25 & 25 \\
$\mathbf{3}$ & Moderate & 0 & 0 \\
$\mathbf{4}$ & Low & 0 & 0 \\
\hline Total & & 100 & 100 \\
\hline
\end{tabular}

The results showed a positive and significant influence between parenting styles on the learning achievement of 5th-grade students of SD Muhammadiyah 18 Surabaya. It showed through a simple regression test $r_{-}(x 1, y)$ with a coefficient of 0.09 . A determinant coefficient of $r_{-}(x 2, y)$ or the contribution of parenting influence on learning achievement is $8 \%$. Thus, the parenting style affects the learning achievement of grade 5 students of SD Muhammadiyah 18 Surabaya.

The results showed a positive and significant influence between adversity on the learning achievement of 
grade 5 students of SD Muhammadiyah 18 Surabaya. It showed through a simple regression test $r_{x 2, y}$ with the results of the coefficient of 0.15 and the determinant coefficient of $r_{-}(2 x, y)$ or the contribution of parenting on learning achievement is $23 \%$. Thus, the parenting style affected the learning achievement of grade 5 students of SD Muhammadiyah 18 Surabaya.

The results showed a positive and significant influence between parenting (X1) and Adversity (X2) on the learning achievement of 5th-grade students of SD Muhammadiyah 18 Surabaya, which was shown through multiple regression tests $(\mathrm{R} 1,2)$ with the results of the coefficient of 0.28 and the coefficient of determination

$r_{2 x, y}$ or the contribution of the influence of parenting on learning achievement is $23 \%$. Thus, parenting style and adversity collectively did not affect student achievement in grade 5 SD Muhammadiyah 18 Surabaya as much as $8.1 \%$.

\section{Discussion}

From the research results, parenting style and adversity affect learning achievement shown in covering parenting styles, adversity, and learning achievement of students at Muhammadiyah 18 Elementary School Surabaya; on average, $97 \%$ of SD Muhammadiyah 18 have parenting styles. It is high parents and 3\% very high parenting style. According to (Zhang et al., 2020) parenting was a pattern of interaction between children and parents; fulfillment of physical (for example, eating, drinking \& others) and psychological needs (for example, a sense of security, affection, protection, others.). It was also by their socialization of residents' prevailing habits so that children can live in harmony with their environment (Yalçıntuğ \& Ayar, 2020),(X. Chen et al., 2020).This process also involves how caregivers (parents) communicate their children's values of effectiveness, interests, behavior, and beliefs (Walker, 2020)."

Specifically, three types of parenting are often practiced byparents, namely authoritatively and permissively (Rebecka et al., 2020), (Yang He et al., 2020).The type of parenting again consists of authoritative parenting; namely, authoritative parents are more flexible and can control and use the control, but they are also accepting and responsive. Second, it is authoritarian parenting, which combines high control and low responsiveness. The third is permissive parenting, namely that parenting contains low control and high responsiveness (Manoli et al., 2020), (Fonseca et al., 2020). Parents can be a benchmark in making children go odor bad in their present and future lives of the four parenting styles (Ernst et al., 2020).

In addition to parenting patterns, learning achievement was also because of adversities on children to produce better learning achievement (Paul \& Singh, 2020), (Putwain et al., 2020). Then it included from the research results, namely adversity data based upon the results of research from 100 grade 5 students of SD Muhammadiyah 18 Surabaya. In general, it can be said that $62 \%$ have very high adversity and $38 \%$ have high adversity (Hendrix et al., 2020). So, in this case, each individual has high and low adversity intelligence (Putwain et al., 2020), (Pierce et al., 2020). The individual characteristics of students who have high adversity intelligence, among others, are optimistic, persistent, and resilient in dealing with problems, think and act carefully and wisely (Yuqiong He et al., 2021).

So it can be concluded that adversity is a person's ability to use intelligence in dealing with and managing problems regularly and continuously to solve problems (Putwain et al., 2020). In this case, adversity is the intelligence that a person has in overcoming difficulties and surviving (Kroska et al., 2020). Adversity can also affect students' learning achievement (Morard et al., 2018), (Dvorsky et al., 2021). The research data can confirm that $75 \%$ of students have very high learning achievement with the highest score of 100 and the lowest is 80 so that the learning achievement of students is successful with above average according to the facts. It showed that students' adversity is achieved and is said to be successful in the educational process.

Learning achievement itself is the result achieved, whether it was done and so on, pleasing to the heart and obtained by persistence in work (Lycko \& Galanakis, 2019), (Naik et al., 2020). In contrast, self-study is a series of mental and physical, psychic activities leading to the development of the whole human person, which involves the elements of creativity, taste, and intention, the cognitive, affective, and psychomotor domains (Hammami et al., 2019), (Knoop-van Campen et al., 2020). Based upon the opinion (Dauvergne et al., 2018), learning achievement is the result obtained in the form of impressions that result in changes in the individual student due to activities in learning (Hayes, 2020).

\section{CONCLUSION}

Based upon the results of the research and discussion carried out, it can be concluded that (1) there is a positive and significant influence between parenting styles on the achievement of 5th-grade students of SD Muhammadiyah 18 Surabaya, (2) there is a positive and significant influence between adversity on the achievement of grade 5 students. SD Muhammadiyah 18 Surabaya and (3) there was a positive and significant influence between parenting (X1) and adversity (X2) on the learning achievement of grade 5 students at SD Muhammadiyah 18 Surabaya. It was shown through multiple regression tests $(\mathrm{R} 1,2)$ with a coefficient of 0.28 , 
and the determinant coefficient of $\mathrm{r}(2 \mathrm{x}, \mathrm{y})$ or the contribution of the influence of parenting on learning achievement is $23 \%$. Thus, parenting style and adversity collectively do not affect student achievement in grade 5 SD Muhammadiyah 18 Surabaya as much as $8.1 \%$. Further research is necessary to pay attention to other factors that allow more influence on the independent variable of student learning achievement, namely related to students' intelligence and mental.

\section{ACKNOWLEDGEMENTS}

I would like to express my deepest gratitude to Universitas Muhammadiyah Surabaya (UMS) and Universitas Negeri Surabaya (UNESA) which facilitate me in conducting the article as well as to IISTE which publishes the article.

\section{REFERENCE}

Bai, S., Hew, K. F., \& Huang, B. (2020). Does gamification improve student learning outcome? Evidence from a meta-analysis and synthesis of qualitative data in educational contexts. Educational Research Review, 30(June 2019), 100322. https://doi.org/10.1016/j.edurev.2020.100322

Benoy, J., \& Morley, M. J. (2020). Out of India: Towards a conceptual framework on internationalization motives, parenting styles and human resource management practices among Indian MNE subsidiaries in Ireland. Human Resource Management Review, 30(4), 100724. https://doi.org/10.1016/j.hrmr.2019.100724

Børsting, T. E., Kristensen, N., \& Hanssen, I. (2020). Student nurses' learning outcomes through participation in a clinical nursing research project: A qualitative study. Nurse Education in Practice, 43(October 2018), 102727. https://doi.org/10.1016/j.nepr.2020.102727

Brosnan, T., Kolubinski, D. C., \& Spada, M. M. (2020). Parenting styles and metacognitions as predictors of cannabis use. Addictive Behaviors 100259. https://doi.org/10.1016/j.abrep.2020.100259

Chen, G., He, J., Cai, Z., \& Fan, X. (2020). Perceived parenting styles and body appreciation among Chinese adolescents: Exploring the mediating roles of dispositional mindfulness and self-compassion. Children and Youth Services Review, 119, 105698. https://doi.org/10.1016/j.childyouth.2020.105698

Chen, I. C., Hwang, G. J., Lai, C. L., \& Wang, W. C. (2020). From design to reflection: Effects of peer-scoring and comments on students' behavioral patterns and learning outcomes in musical theater performance. Computers and Education, 150(August 2019), 103856. https://doi.org/10.1016/j.compedu.2020.103856

Chen, X., Liu, T., Luo, J., \& Ren, S. (2020). Data for teenagers' stressor, mental health, coping style, social support, parenting style and self-efficacy in South China. Data in Brief, 29, 105202. https://doi.org/10.1016/j.dib.2020.105202

Cheng, T. W., Mills, K. L., Miranda Dominguez, O., Zeithamova, D., Perrone, A., Sturgeon, D., Feldstein Ewing, S. W., Fisher, P. A., Pfeifer, J. H., Fair, D. A., \& Mackiewicz Seghete, K. L. (2021). Characterizing the impact of adversity, abuse, and neglect on adolescent amygdala resting-state functional connectivity. Developmental Cognitive Neuroscience, 47, 100894. https://doi.org/10.1016/j.dcn.2020.100894

Covin, J. G., Garrett, R. P., Kuratko, D. F., \& Shepherd, D. A. (2020). Short leash or long leash? Parenting style, initial strategic clarity, and the development of venture learning proficiency. Journal of Business Venturing, 35(4), 105951. https://doi.org/10.1016/j.jbusvent.2019.105951

Dauvergne, C., B égel, V., G ény, C., Puyjarinet, F., Laffont, I., \& Dalla Bella, S. (2018). Home-based training of rhythmic skills with a serious game in Parkinson's disease: Usability and acceptability. Annals of Physical and Rehabilitation Medicine, 61(6), 380-385. https://doi.org/10.1016/j.rehab.2018.08.002

Deng, L., \& Tong, T. (2020). Parenting style and the development of noncognitive ability in children. China Economic Review, 62(March 2019), 101477. https://doi.org/10.1016/j.chieco.2020.101477

DeZelar, S., \& Lightfoot, E. (2020). Who refers parents with intellectual disabilities to the child welfare system? An analysis of referral sources and substantiation. Children and Youth Services Review, 119(October), 105639. https://doi.org/10.1016/j.childyouth.2020.105639

Dragan, M. (2020). Adverse experiences, emotional regulation difficulties and psychopathology in a sample of young women: Model of associations and results of cluster and discriminant function analysis. European Journal of Trauma \& Dissociation, 4(1), 100091. https://doi.org/10.1016/j.ejtd.2018.12.001

Dvorsky, M. R., Friedman, L. M., Spiess, M., \& Pfiffner, L. J. (2021). Patterns of Parental Adherence and the Association to Child and Parenting Outcomes Following a Multicomponent School-Home Intervention for Youth With ADHD. Behavior Therapy. https://doi.org/10.1016/j.beth.2020.09.007.

Ernst, M., Brähler, E., Klein, E. M., Jünger, C., Wild, P. S., Faber, J., Schneider, A., \& Beutel, M. E. (2020). What's past is prologue: Recalled parenting styles are associated with childhood cancer survivors' mental health outcomes more than 25 years after diagnosis. Social Science and Medicine, 252(March), 112916. https://doi.org/10.1016/j.socscimed.2020.112916

Fluss, J., \& Lidzba, K. (2020). Cognitive and academic profiles in children with cerebral palsy: A narrative 
review. Annals of Physical and Rehabilitation Medicine, 63(5), 447-456. https://doi.org/10.1016/j.rehab.2020.01.005

Fonseca, A., Moreira, H., \& Canavarro, M. C. (2020). Uncovering the links between parenting stress and parenting styles: The role of psychological flexibility within parenting and global psychological flexibility. Journal of Contextual Behavioral Science, 18(July), 59-67. https://doi.org/10.1016/j.jcbs.2020.08.004

Furusawa, M., \& Brewster, C. (2019). The Determinants of the Boundary-spanning Functions of Japanese Selfinitiated Expatriates in Japanese Subsidiaries in China: Individual Skills and Human Resource Management. Journal of International Management, 25(4), 100674. https://doi.org/10.1016/j.intman.2019.05.001

Gatti, L., Ulrich, M., \& Seele, P. (2019). Education for sustainable development through business simulation games: An exploratory study of sustainability gamification and its effects on students' learning outcomes. Journal of Cleaner Production, 207, 667-678. https://doi.org/10.1016/j.jclepro.2018.09.130

Gerritsen-van Leeuwenkamp, K. J., Joosten-ten Brinke, D., \& Kester, L. (2019). Students' perceptions of assessment quality related to their learning approaches and learning outcomes. Studies in Educational Evaluation, 63(July 2018), 72-82. https://doi.org/10.1016/j.stueduc.2019.07.005

Gralewski, J., \& Jankowska, D. M. (2020). Do parenting styles matter? Perceived dimensions of parenting styles, creative abilities and creative self-beliefs in adolescents. Thinking Skills and Creativity, 38(May), 100709. https://doi.org/10.1016/j.tsc.2020.100709

Guo, J. (2018). Building bridges to student learning: Perceptions of the learning environment, engagement, and learning outcomes among Chinese undergraduates. Studies in Educational Evaluation, 59(April), 195-208. https://doi.org/10.1016/j.stueduc.2018.08.002

Guo, P., Saab, N., Post, L. S., \& Admiraal, W. (2020). A review of project-based learning in higher education: Student outcomes and measures. International Journal of Educational Research, 102(May), 101586. https://doi.org/10.1016/j.ijer.2020.101586

Hammami, S., Saeed, F., Mathkour, H., \& Arafah, M. A. (2019). Continuous improvement of deaf student learning outcomes based on an adaptive learning system and an Academic Advisor Agent. Computers in Human Behavior, 92, 536-546. https://doi.org/10.1016/j.chb.2017.07.006

Hayes, S. (2020). Socialising students for Philosophic Practice? An analysis of learning outcomes in tourism taught Master's programmes. Journal of Hospitality, Leisure, Sport and Tourism Education, xxxx, 100274. https://doi.org/10.1016/j.jhlste.2020.100274

He, Yang, Liu, C., Chen, Y., Huang, J., \& Luo, R. (2020). Intergenerational transmission of parenting style in rural China and the mediation effect of Caregiver's mental health. Children and Youth Services Review, 117(April), 105319. https://doi.org/10.1016/j.childyouth.2020.105319

He, Yuqiong, Zhang, Y., Cui, X., Zhong, Y., He, W., Liu, J., Luo, X., \& Gong, J. (2021). Epidemiology of major childhood adversities and its effect on depression and suicide attempts in Chinese college students. Journal of Affective Disorders, 281, 331-337. https://doi.org/10.1016/j.jad.2020.12.031

Hendrix, C. L., Dilks, D. D., McKenna, B. G., Dunlop, A. L., Corwin, E. J., \& Brennan, P. A. (2020). Maternal childhood adversity associates with frontoamygdala connectivity in neonates. Biological Psychiatry: Cognitive Neuroscience and Neuroimaging. https://doi.org/10.1016/j.bpsc.2020.11.003

Horning, M. L., Ostrow, L., Beierwaltes, P., Beaudette, J., Schmitz, K., \& Fulkerson, J. A. (2020). Service learning within community-engaged research: Facilitating nursing student learning outcomes. Journal of Professional Nursing, 36(6), 510-513. https://doi.org/10.1016/j.profnurs.2020.04.005

Huizenga, J., Admiraal, W., Dam, G. ten, \& Voogt, J. (2019). Mobile game-based learning in secondary education: Students' immersion, game activities, team performance and learning outcomes. Computers in Human Behavior, 99(April), 137-143. https://doi.org/10.1016/j.chb.2019.05.020

Knoop-van Campen, C. A. N., Segers, E., \& Verhoeven, L. (2020). Effects of audio support on multimedia learning processes and outcomes in students with dyslexia. Computers and Education, 150(June 2019), 103858. https://doi.org/10.1016/j.compedu.2020.103858

Kroska, E. B., Roche, A. I., Adamowicz, J. L., \& Stegall, M. S. (2020). Psychological flexibility in the context of COVID-19 adversity : Associations with distress. Journal of Contextual Behavioral Science, 18(June), 2833. https://doi.org/10.1016/j.jcbs.2020.07.011

Kumpas-Lenk, K., Eisenschmidt, E., \& Veispak, A. (2018). Does the design of learning outcomes matter from students' perspective? Studies in Educational Evaluation, 59(January), 179-186. https://doi.org/10.1016/j.stueduc.2018.07.008

Kyriakides, L., Stylianou, A., \& Eliophotou Menon, M. (2019). The link between educational expenditures and student learning outcomes: Evidence from Cyprus. International Journal of Educational Development, 70(June), 102081. https://doi.org/10.1016/j.ijedudev.2019.102081

Lavrič, M., \& Naterer, A. (2020). The power of authoritative parenting: A cross-national study of effects of exposure to different parenting styles on life satisfaction. Children and Youth Services Review, 116(July). https://doi.org/10.1016/j.childyouth.2020.105274 
Logan, R. M., Johnson, C. E., \& Worsham, J. W. (2020). Development of an e-learning module to facilitate student learning and outcomes. Teaching and Learning in Nursing, 000, 7-10. https://doi.org/10.1016/j.teln.2020.10.007

Luo, Y., Chen, F., Zhang, X., Zhang, Y., Zhang, Q., Li, Y., Zhou, Q., \& Wang, Y. (2021). Profiles of maternal and paternal parenting styles in Chinese families: Relations to preschoolers' psychological adjustment. Children and Youth Services Review, 105787. https://doi.org/10.1016/j.childyouth.2020.105787

Lycko, M., \& Galanakis, K. (2019). Student consultancy projects playbook: Learning outcomes and a framework for teaching practice in an international entrepreneurial context. International Journal of Management Education, January, 100285. https://doi.org/10.1016/j.ijme.2019.02.005

Maftei, A., Holman, A. C., \& Cârlig, E. R. (2020). Does your child think you're happy? Exploring the associations between children's happiness and parenting styles. Children and Youth Services Review, 115(May), 105074. https://doi.org/10.1016/j.childyouth.2020.105074

Manoli, R., Chartaux-Danjou, L., Delecroix, H., Daveluy, W., Torre, F., \& Moroni, C. (2020). Machine learning modelling of neuropsychological performance could determine vocational training outcome after a brain injury: Case report. Annals of Physical and Rehabilitation Medicine. https://doi.org/10.1016/j.rehab.2020.01.009

Mönkediek, B., Schulz, W., Eichhorn, H., \& Diewald, M. (2020). Is there something special about twin families? A comparison of parenting styles in twin and non-twin families. Social Science Research, 90(May 2019). https://doi.org/10.1016/j.ssresearch.2020.102441

Morard, M. D., Gonzalez-Monge, S., Rippert, P., Roche, S., Bernard, J. C., Lagauche, D., Delvert, C., Luaut é, J., Jacquin-Courtois, S., Caillet, F., Di Marco, J., Ghelfi, F., Otmani, S., Calmels, P., Royet, M., Joseph, P. A., Ecochard, R., Rode, G., \& Vuillerot, C. (2018). Construction and feasibility study of the SOFMER Activity Score (SAS), a new assessment of physical and cognitive activity. Annals of Physical and Rehabilitation Medicine, 61(5), 315-322. https://doi.org/10.1016/j.rehab.2018.04.006

Naik, G., Chitre, C., Bhalla, M., \& Rajan, J. (2020). Impact of use of technology on student learning outcomes: Evidence from a large-scale experiment in India. World Development, 127, 104736. https://doi.org/10.1016/j.worlddev.2019.104736

O’Connor, M., Ponsonby, A.-L., Collier, F., Liu, R., Sly, P. D., Azzopardi, P., Lycett, K., Goldfeld, S., Arnup, S. J., Burgner, D., Priest, N., Vuillermin, P., Tang, M. L. K., Saffery, R., Carlin, J., \& Harrison, L. (2020). Exposure to adversity and inflammatory outcomes in mid and late childhood. Brain, Behavior, \& Immunity - Health, 9(September), 100146. https://doi.org/10.1016/j.bbih.2020.100146

O’Dea, N., Clough, M., Beebe, R., DiVietro, S., Lapidus, G., \& Grasso, D. J. (2020). Using Child Protective Services Case Record Data to Quantify Family-Level Severity of Adversity Types, Poly-victimization, and Poly-deprivation. Child Abuse and Neglect, 108(December 2019), 104688. https://doi.org/10.1016/j.chiabu.2020.104688

Oh, J. W., Huh, B., \& Kim, M. R. (2019). Effect of learning contracts in clinical pediatric nursing education on students' outcomes: A research article. Nurse Education Today, 83(August), 104191. https://doi.org/10.1016/j.nedt.2019.08.009

Paul, R., \& Singh, A. (2020). Does early childhood adversities affect physical, cognitive and language development in indian children? Evidence from a panel study. SSM - Population Health, 12(August), 100693. https://doi.org/10.1016/j.ssmph.2020.100693

Pierce, M., Abel, K. M., Muwonge, J., Wicks, S., Nevriana, A., Hope, H., Dalman, C., \& Kosidou, K. (2020). Prevalence of parental mental illness and association with socioeconomic adversity among children in Sweden between 2006 and 2016: a population-based cohort study. The Lancet Public Health, 5(11), e583e591. https://doi.org/10.1016/S2468-2667(20)30202-4

Putwain, D. W., Gallard, D., \& Beaumont, J. (2020). Academic buoyancy protects achievement against minor academic adversities. Learning and Individual Differences, 83-84(September), 101936. https://doi.org/10.1016/j.lindif.2020.101936

Qin, X., Feng, Y., Qu, F., Luo, Y., Chen, B., Chen, M., Zou, Y., \& Zhang, L. (2020). Posttraumatic growth among parents of children with autism spectrum disorder in China and its relationship to family function and mental resilience: A cross-sectional study. Journal of Pediatric Nursing. https://doi.org/10.1016/j.pedn.2020.10.026

Rebecka, K., Susanne, O., Kent, N. W., \& Cecilia, Å. (2020). The influence of parenting styles and parental depression on adolescent depressive symptoms: A cross-sectional and longitudinal approach. Mental Health and Prevention, 20(October), 200193. https://doi.org/10.1016/j.mhp.2020.200193

Roh, Y. S., Jang, K. I., \& Issenberg, S. B. (2020). Nursing students' perceptions of simulation design features and learning outcomes: The mediating effect of psychological safety. Collegian, 2-7. https://doi.org/10.1016/j.colegn.2020.06.007

Sharma, R. R. (2019). Cultural Intelligence and Institutional Success: The Mediating Role of Relationship 
Quality. Journal of International Management, 25(3), 100665. https://doi.org/10.1016/j.intman.2019.01.002

Si, S., Su, Y., Zhang, S., \& Zhang, J. (2020). Genetic susceptibility to parenting style: DRD2 and COMT influence creativity. NeuroImage, 213(88). https://doi.org/10.1016/j.neuroimage.2020.116681

Sierra, J. (2020). The potential of simulations for developing multiple learning outcomes: The student perspective. International Journal of Management Education, 18(1), 100361. https://doi.org/10.1016/j.ijme.2019.100361

Stern, A., Rosenthal, Y., Dresler, N., \& Ashkenazi, D. (2019). Additive manufacturing: An education strategy for engineering students. Additive Manufacturing, 27(March), 503-514. https://doi.org/10.1016/j.addma.2019.04.001

Sumiyoshi, T., Yokono, T., Kawachi, I., \& Suzuki, T. (2020). Learning outcomes of interprofessional collaboration among medical and nursing students in Japan. Journal of Interprofessional Education and Practice, 21, 100377. https://doi.org/10.1016/j.xjep.2020.100377

Valashjardi, A., MacLean, R., \& Charles, K. (2020). Recollections of parenting styles in the development of narcissism: The role of gender. Personality and Individual Differences, 167(July), 110246. https://doi.org/10.1016/j.paid.2020.110246

van Herwijnen, I. R., van der Borg, J. A. M., Naguib, M., \& Beerda, B. (2020). Dog-directed parenting styles predict verbal and leash guidance in dog owners and owner-directed attention in dogs. Applied Animal Behaviour Science, 232, 105131. https://doi.org/10.1016/j.applanim.2020.105131

Walker, D. K. (2020). Parenting and social determinants of health. Archives of Psychiatric Nursing, October. https://doi.org/10.1016/j.apnu.2020.10.016

Woo, E. M. W., Serenko, A., \& Chu, S. K. W. (2019). An exploratory study of the relationship between the use of the Learning Commons and students' perceived learning outcomes. Journal of Academic Librarianship, 45(4), 413-419. https://doi.org/10.1016/j.acalib.2019.05.007

Xia, X. (2020). Parenting style and Chinese children's school readiness outcomes: The moderating role of socioeconomic status. Children and Youth Services Review, 118(April), 105381. https://doi.org/10.1016/j.childyouth.2020.105381

Yaffe, Y. (2020). Does self-esteem mediate the association between parenting styles and imposter feelings among female education students? Personality and Individual Differences, 156(September 2019), 109789. https://doi.org/10.1016/j.paid.2019.109789

Yalçıntuğ, F. M., \& Ayar, D. (2020). Psychometric properties of the Turkish version of the epilepsy-related fears in parents questionnaire. Journal of Pediatric Nursing. https://doi.org/10.1016/j.pedn.2020.10.009

Yang, X., Fan, C., Liu, Q., Chu, X., Song, Y., \& Zhou, Z. (2020). Parenting styles and children's sleep quality: Examining the mediating roles of mindfulness and loneliness. Children and Youth Services Review, 114(March), 104921. https://doi.org/10.1016/j.childyouth.2020.104921

Zhang, H., Qin, X., \& Zhou, J. (2020). Do tiger moms raise superior kids? The impact of parenting style on adolescent human capital formation in China. China Economic Review, 63(August), 101537. https://doi.org/10.1016/j.chieco.2020.101537 